\title{
Oyster Mushroom Addition on Nutritional Composition and Sensory Evaluation of Herbal Seasoning
}

\author{
Ita Fatkhur Romadhoni, Siti Yuliana, Luthfiyah Nurlela \\ Department of Home Economics \\ Universitas Negeri Surabaya \\ Ketintang, Surabaya, 60231, Indonesia \\ itaromadhoni@unesa.ac.id
}

\begin{abstract}
Herbal seasoning on food has been developed and studied. It is recommended by some experts in the field of research experts not to consume MSG present in food, but other experts who understand it say no problem consuming MSG on food origin is still within the threshold of tolerance. The purpose of this study was to develop a natural flavor enhancer made with the basic ingredients of mushrooms. The presence of natural glutamate acid content contained in the fungus, it needs to be made flavor derived from mushrooms. The flavoring experiment was made from three types of mushrooms, namely oysters, Shiitake, and straw mushroom. Findings show the result of organoleptic taste flavor test, it can be concluded that commercial flavor taste has the highest values. The four flavors of mushroom tested, flavoring of straw mushroom is more dominant than the others, with a higher value of satiety, but in terms of aroma and color more attractive flavor of oyster mushrooms. It is expected that the fungus can be as an alternative condiment flavor is tasty and safe for health, both for the present and the future.
\end{abstract}

Keywords-Glutamic acid; savory; natural flavors; Oyster mushroom (Pleurotus ostreatus); Shiitake (Lentinus edodes); Straw mushroom (Volvariella Volvacea).

\section{INTRODUCTION}

In recent years, oyster mushroom have received increasing interest as potential herbal seasonings [1]. Nutrition content is good enough of folic acid (vitamin B-complex) tall and can cure anemia and anti-tumor drugs, prevent and combat malnutrition and treatment of iron deficiency. sensory evaluation investigating interactions between Steamed garlic and oyster mushroom can make a significant contribution to improve understanding of the diverse effects of herbal seasoning on the monosodium glutamate flavor based on oyster mushroom seasoning [2].

Herbal seasoning is one type of flavoring ingredient or food that can be stored and durable, the herb also is dry. A mixture of various herbs and spices are mixed and processed with a specific composition. There are two types of instant seasoning, pasty and dry or powdered form.
This proof-of-concept sensory study provides the basis for how mushrooms and meat can combine for healthier alternatives to iconic American dishes. As the study shows, a traditional ground meat recipe prepared with 50 percent mushrooms and 50 percent meat (or even 80 percent mushrooms and 20 percent meat) can reduce calorie, fat and sodium intake, while adding nutrients like vitamin D, potassium*, b-vitamins and antioxidants. Not only enhance the overall flavor, because of double the impact of umami but also maintain flavor while reducing sodium intake by 25 percent [3]. The Glutamate Association estimates that mushrooms contain about 180 milligrams per 100 grams of free glutamate. Shiitake have the highest content of 2.579 grams per 100 grams. In comparison, milk contains 2 grams of glutamate in 100 grams against 100 grams of Parmesan cheese contains 1,200 milligrams of glutamate [4].

Mushrooms have many specials taste, much in demand because it gives delicious and savory flavors in the world. Glutamate naturally in mushrooms gives the same delicious taste like the meat for vegetarians. Glutamate is an amino acid found in all protein foods. Level glutamate in mushrooms will increase when the mushrooms are grown old enough to be harvested. Sense of natural glutamate can also be found in Parmesan cheese, soy sauce, anchovies, tomato juice, Vegemite and Marmite. By extra glutamate added to foods, the salt content can be reduced to $30-40 \%$ without affecting the taste of savory [5]. It is suggested that by adding the fungus on food, salt consumption can be reduced, even without salt altogether and let the flavor of the mushrooms as flavor. Salt in the diet is known as sodium chloride, with parts of sodium contributes to high blood pressure. Food labels list the sodium and the food is less than $120 \mathrm{mg}$ of salt per 100 grams is considered a low-salt foods. Mushrooms are naturally low in sodium, fat, cholesterol, and calories and often referred to as functional food. In addition to providing the basic nutrients, they help get back chronic diseases because of their antioxidant and dietary fiber useful as chitin and beta-glucan [6]. 


\section{METHODS}

\section{A. Preparation of oyster mushroom powder}

Oyster mushroom were supplied by Yuliana Manufacturing. A local small company in Sidoarjo, Indonesia. The dried samples were ground into powder form by using food grinder (National MX 895M) and kept in a sealable plastic bag prior to analysis.

\section{B. Preparation of herbal seasoning}

The herbal seasoning were prepared by using a mixture of locally available herbs, blended spices, oyster mushroom powder and steamed garlic. All local culinary herbs were purchased from local wet markets. Steamed garlic was substituted with oyster mushroom powder at the level of $0 \%$ (M1), 25\% (M2), 45\% (M3), 65\% (M4), 85\% (M5) and 100\% (M6). The composite powders and other dry ingredients were mixed with culinary herbs in a jacketed kettle before distilled water was added.

\section{Sensory evaluation}

Sensory evaluations were carried out by 50 untrained consumers consisting of students and staffs of the State University of Surabaya, Home Economics Department. They evaluate samples for aroma, color, viscosity, hotness, sourness, aftertaste and overall acceptability on a 7 point scale $(1=$ dislike extremely and $7=$ like extremely).

\section{Data analysis}

Data were analyzed according to one-way ANOVA by using SPSS 19.0. Results were expressed as mean \pm standard deviation. All measurements were carried out in triplicate $(n=$ 3). Significant level was established at $\mathrm{P}<0.05$.

\section{RESULT AND DISCUSSION}

\section{A. Proximate compositions}

Proximate composition of herbal enriched oyster mushroom content of the different level samples was measured in two different temperatures with two different cooking method based test kits, steamed and boiled. Powders with six different formulations are shown in Table 2. The addition of mushroom powder has resulted significantly increased $(p<0.05)$ of moisture content and protein content while at the same time was significantly decreased $(\mathrm{p}<0.05)$ in fat content.
However, these changes were only significant $(\mathrm{p}<0.05)$ when PSC powder was added in the herbal seasoning formulations. Herbal seasoning added with oyster mushroom powder had moisture content in the range of $58.76 \%$ to $62.69 \%$. Proximate analysis indicated that herbal seasoning substitute with more than $60 \%$ PSC powder had higher moisture content.

The moisture content of control sample was the lowest $(58.76 \%)$ and the HS with $80 \%$ substitution of PSC powder $(62.69 \%)$ had the highest moisture content. However, sample with $40 \%$ PSC powder substitution and higher were not significant different $(\mathrm{p}>0.05)$ among each other. Generally, fresh mushroom (Pleurotus Species) contains $85-95 \%$ moisture [7]. Oyster powder possess high water content and water holding capacity that linked to the higher moisture content in herbal seasoning added with oyster mushroom powder. It was from the sugar and dietary fiber (starch) available in oyster mushroom powder which may absorb large amount of water content [8]. Analysis of composition of herbal enriched oyster mushroom content (Supplementary fig. 1).

TABLE 1. HERBAL SEASONING FORMULATED WITH DIFFERENT LEVEL OF OYSTER MUSHROOM POWDER

\begin{tabular}{|l|c|c|c|c|c|c|}
\hline \multicolumn{7}{|c|}{ Oyster Mushroom Powder (\%) } \\
\hline Ingredients (\%) & 0 & 25 & 45 & 65 & 85 & 100 \\
\hline Mushroom Powder & 0 & 5 & 9 & 13 & 17 & 19 \\
\hline Cumin Powder & 0.4 & 0.4 & 0.4 & 0.4 & 0.4 & 0.4 \\
\hline Salt & 2.0 & 2.0 & 2.0 & 2.0 & 2.0 & 2.0 \\
\hline Ginger & 1.2 & 1.2 & 1.2 & 1.2 & 1.2 & 1.2 \\
\hline Turmeric & 1.0 & 1.0 & 1.0 & 1.0 & 1.0 & 1.0 \\
\hline Garlic & 25 & 18 & 14 & 10 & 8 & 0 \\
\hline
\end{tabular}

In addition, high dietary fiber and protein content could contribute to the increase of water holding capacity resulting higher water absorption of oyster mushroom powder. The viscosity of HS increased significantly with the addition of herbal seasoning powder, while the yield was decreased upon the addition level of oyster mushroom powder introduced in HS formulations. The present findings were in agreement with on the addition of Oyster mushroom powder to substitute wheat powder in bread making. They found that the loaf weight increased, while the loaf volumes decreased. On the other hand, the concentration of fat was inversely proportional to the PSC powder levels in herbal seasoning. All data reported on dry basis. Generally, herbal seasoning had relatively high in fat content ranged from $8.16 \%$ to $13.82 \%$ which was not surprising for all garlic-based foods.

TABLE 2 PROXIMATE ANALYSIS OF HERBAL SEASONING INTEGRATED WITH OYSTER MUSHROOM POWDER

\begin{tabular}{|l|c|c|c|c|c|c|}
\hline \multirow{2}{*}{ Proximate } & \multicolumn{5}{|c|}{ Treatment } \\
\cline { 2 - 7 } & M1 (0\%) & M2 (20\%) & M3 (40\%) & M4 (60\%) & M5 (80\%) & M6 (100\%) \\
\hline Carbohydrate & $47.56 \pm 0.87^{\mathrm{a}}$ & $46.26 \pm 0.97^{\mathrm{b}}$ & $45.78 \pm 0.30^{\mathrm{c}}$ & $45.35 \pm 0.69^{\mathrm{c}}$ & $43.32 \pm 0.24^{\mathrm{d}}$ & $45.56 \pm 0.57^{\mathrm{c}}$ \\
\hline Fat & $14.34 \pm 0.72^{\mathrm{a}}$ & $13.35 \pm 0.62^{\mathrm{b}}$ & $12.17 \pm 0.65^{\mathrm{c}}$ & $11.15 \pm 0.19^{\mathrm{c}}$ & $10.12 \pm 0.47^{\mathrm{d}}$ & $9.56 \pm 0.36^{\mathrm{c}}$ \\
\hline Protein & $7.16 \pm 0.27^{\mathrm{f}}$ & $8.76 \pm 0.17^{\mathrm{e}}$ & $9.88 \pm 0.20^{\mathrm{d}}$ & $10.75 \pm 0.79^{\mathrm{c}}$ & $11.22 \pm 0.27^{\mathrm{b}}$ & $11.96 \pm 0.77^{\mathrm{a}}$ \\
\hline Moisture & $57.56 \pm 2.87^{\mathrm{c}}$ & $59.16 \pm 3.97^{\mathrm{bc}}$ & $62.08 \pm 2.30^{\mathrm{ac}}$ & $63.36 \pm 3.69^{\mathrm{c}}$ & $63.92 \pm 3.74^{\mathrm{d}}$ & $63.56 \pm 3.51^{\mathrm{c}}$ \\
\hline Ash & $17.16 \pm 0.18^{\mathrm{a}}$ & $15.27 \pm 0.27^{\mathrm{b}}$ & $15.48 \pm 0.70^{\mathrm{c}}$ & $15.65 \pm 0.69^{\mathrm{c}}$ & $13.98 \pm 0.24^{\mathrm{d}}$ & $14.19 \pm 0.37^{\mathrm{c}}$ \\
\hline
\end{tabular}

On the other hand, the introduction of garlic at amount of $6.3 \%$ showed the total fat content of product is consider high. herbal seasoning prepared from herbal seasoning $(\mathrm{F})$ was significantly $(\mathrm{p}<0.05)$ recorded the lowest in fat $(8.61 \%)$ 
content than other treatments. In addition, HS (E) ranked the second lower in fat content $(9.25 \%)$. As expected, the highest fat content was recorded in control sample which was $13.82 \%$. The highest fat content was corresponded to the lowest moisture content detected in control herbal seasoning. Ash content was generally high in all treatments ranging from $14.27 \%$ to $15.72 \%$. Basically, ash content gives a rough idea about the mineral content of the product. Interestingly, changes in proximate composition of herbal seasoning added with oyster mushroom powder resulted factors and stage of fruiting body maturity, but also on species. The increase in these chemical compositions could be probably due to their high quantities of nutritional composition in oyster mushroom powder. According to [9] cereals such as wheat flour are lower in protein and lysine deficient but rich in sulphur containing amino acid. Furthermore, protein, carbohydrate and ash content of mushrooms are also significantly affected by their technological process [10]. The highest protein and the lowest fat percentage in HS (F) may due to the moderate amount of protein $(23.3 \%)$ and fat content $(3.0 \%)$ existing originally in dried PSC powder used in this study [11]. Furthermore, the dry matter of mushroom fruit bodies is about $5-15 \%$. They also have a very low fat content and contain $19-35 \%$ proteins. Meanwhile, control sample (A) had the lowest protein content (7.12\%). The protein content showed the increasing trend in line with the PSC powder substitution. Interestingly, the nutritional value of mushrooms is primarily related to their protein content. In fact, mushroom protein is considered to have higher nutritional quality than that of plant proteins [12]. [13] Mentioned that the protein content of mushroom is not only dependent on environmental ash content $(1.23 \mathrm{~g} / 100 \mathrm{~g})$ compared to the control for protein $(1.12 \mathrm{~g} / 100 \mathrm{~g})$ and ash content $(0.7 \mathrm{~g} / 100 \mathrm{~g})$ respectively. On the other hand, carbohydrate content was reduced as a result of PSC powder addition in the HS formulations in the range of $43.75 \%$ $47.71 \%$.

\section{B. Sensory evaluation}

Table 3 shows the values for all sensory attributes of herbal seasoning added with oyster mushroom powder as judged by the untrained panels. They were Sensory evaluations were carried out by 50 untrained consumers consisting of students and staffs of the State University of Surabaya, Home Economics Department. Sensory forms with seven point hedonic scales $(1=$ dislike extremely and $7=$ like extremely) were used to differentiate the panel preferences in degree of liking. Six attributes evaluated were aroma, color, viscosity, hotness, sourness, aftertaste and overall acceptability. Herbal Seasoning was marinated with steamed chicken and served to the panels together with rice. Each sample was placed in a small sample container coded with three random permuted three digit numbers. There was no significant different $(p>0.05)$ recorded in color, viscosity, hotness, sourness, aftertaste and taste attributes in all different levels of PSC added in HS formulations. However, the color and viscosity attributes showed higher values compared to the control sample. The present result shows that panels prefer herbal seasoning formulated with PSC powder in enhancing the color and viscosity attributes [14]. Moreover, there was significant different $(p<0.05)$ recorded in both aroma and overall acceptability in all products. Interestingly, control samples (5.58) showed no significant different $(\mathrm{p}>0.05)$ with the HS (F)(5.06). In fact, control sample for aroma (5.58) recorded the highest value among other attributes and not significant different $(\mathrm{p}>0.05)$ with $\mathrm{HS}(\mathrm{F})(5.06)$. However, other samples showed significant different $(\mathrm{p}<0.05)$ with control samples and $\mathrm{HS}(\mathrm{F})$. For overall acceptability, the highest score was recorded in control sample (5.11) and not significant different $(\mathrm{p}>0.05)$ with $\mathrm{HS}(\mathrm{F})(4.7)$. However $\mathrm{HS}(\mathrm{C})(4.17)$ and $\mathrm{HS}(\mathrm{D})(4.47)$ showed no significant different $(\mathrm{p}>0.05)$ with $\mathrm{HS}(\mathrm{F})(4.7)$. Among all herbal seasoning samples, HS prepared without addition of PSC powder (control) received the highest scores for aroma (5.31), color (5.45), viscosity (4.85), hotness (4.71), sourness (4.03), aftertaste (4.6), and overall acceptability (4.88).

TABLE 3 SENSORY ANALYSIS OF HERBAL SEASONING WITH DIFFERENT OYSTER MUSHROOM LEVEL

\begin{tabular}{|c|c|c|c|c|c|c|}
\hline \multirow[t]{2}{*}{ Atributes } & \multicolumn{6}{|c|}{ Treatment } \\
\hline & M1 (0\%) & M2 (20\%) & M3 (40\%) & M4 (60\%) & M5 $(\mathbf{8 0} \%)$ & M6 (100\%) \\
\hline Aroma & $4.56 \pm 1.87^{\mathrm{a}}$ & $4.26 \pm 1.97^{\mathrm{b}}$ & $4.78 \pm 1.30^{\mathrm{c}}$ & $4.35 \pm 1.69^{\mathrm{c}}$ & $4.32 \pm 1.24^{\mathrm{d}}$ & $5.56 \pm 1.57^{\mathrm{c}}$ \\
\hline Color & $5.34 \pm 1.72^{\mathrm{a}}$ & $5.35 \pm 1.62^{b}$ & $5.78 \pm 1.65^{\mathrm{c}}$ & $4.85 \pm 1.19^{\mathrm{c}}$ & $5.92 \pm 1.47^{\mathrm{d}}$ & $6.56 \pm 1.36^{\mathrm{c}}$ \\
\hline $\begin{array}{l}\text { Viscosity } \\
\end{array}$ & $4.16 \pm 0.27^{\mathrm{f}}$ & $4.76 \pm 0.17^{\mathrm{e}}$ & $4.88 \pm 0.20^{\mathrm{d}}$ & $3.75 \pm 0.79^{c}$ & $4.22 \pm 0.27^{\mathrm{b}}$ & $4.96 \pm 0.77^{\mathrm{a}}$ \\
\hline Sourness & $4.56 \pm 2.87^{\mathrm{C}}$ & $3.16 \pm 3.97^{\mathrm{bc}}$ & $3.08 \pm 2.30^{\mathrm{ac}}$ & $3.36 \pm 3.69^{c}$ & $4.92 \pm 3.74^{\mathrm{d}}$ & $4.56 \pm 3.51^{\mathrm{c}}$ \\
\hline After Taste & $4.16 \pm 0.18^{\mathrm{a}}$ & $4.27 \pm 0.27^{b}$ & $3.48 \pm 0.70^{\mathrm{c}}$ & $4.65 \pm 0.69^{c}$ & $4.98 \pm 0.24^{\mathrm{d}}$ & $4.19 \pm 0.37^{c}$ \\
\hline $\begin{array}{l}\text { Overall } \\
\text { Acceptability }\end{array}$ & $4.19 \pm 0.27^{f}$ & $4.16 \pm 0.17^{\mathrm{e}}$ & $4.18 \pm 0.20^{\mathrm{d}}$ & $3.15 \pm 0.79^{\mathrm{c}}$ & $4.12 \pm 0.27^{b}$ & $5.96 \pm 0.77^{\mathrm{a}}$ \\
\hline
\end{tabular}

Even though control sample recorded the highest scores for viscosity, hotness, aftertaste, sourness and overall acceptability, but it was not significant different with other treatments [15]. HS(F) had received slightly higher ratings for color and viscosity attributes compared to other treatments. To evaluate appearance of all products, attributes of color brightness and viscosity were also considered. PSC powder addition caused an increase in lighter color and decreased the brownish color (data not shown). 


\section{CONCLUSION}

The various applications of nutritive food ingredients will make the food products become healthier for consumption of health conscious consumers. More value added efforts in terms of nutritional and dietary fiber can boost the products to fulfill the needs for the current demands of functional food. The substitution of oyster mushroom powder in herbal seasoning formulation can be applied since the sensory panels unable to differentiate the control sample with oyster mushroom powder-based herbal powder. In brief, the addition of oyster mushroom powder-based to replace MSG inorganic partially resulted in reducing fat, improving protein and dietary fiber while not jeopardizing sensorial attributes of herbal seasoning products. herbal seasoning formulated with more than $40 \%$ oyster mushroom powder is recommended since it has significant nutrients and palatably accepted by sensorial panelists.

\section{ACKNOWLEDGMENT}

Authors would like to thank Home Economics Department for the facilities provided. In addition, sincere appreciations are extended to all the staffs and seniors including Mrs. Dwi Kristiastuti, Mrs. Luthfiyah Nurlaela, Mr. Asrul Bahar and Miss Siti Yuliana in Nutrition lab and Food Preparation lab in the A3 Building, Ketintang campus for their helps and guidance towards the success of this research.

\section{REFERENCES}

[1] Aishah, M. S. and Wan Rosli, W. I. 2013. The effect of addition of oyster mushroom (Pleurotus sajor-caju) on nutrient composition and sensory acceptation of selected wheat and rice-based products. International Food Research Journal 20(1): 183-188.

[2] Colak, A., Faiz, Z. and Sesli, E. 2009. Nutritional composition of some wild edible mushrooms. Turkish Journal of Biochemistry 34: 25-31.

[3] AOAC. 2000. Official Methods of Analysis of the Association of Official Agricultural Chemists. Association of Analytic Chemists, Washington, DC. Pp. 125-139.

[4] Manzi, P., Gambelli, L., Marconi, S., Vivanti, V. and Pizzoferrato, L. 1999. Nutrients in edible mushrooms: an inter-species comparative study. Food Chemistry 65: 477-482.

[5] Manzi, P., Aguzzi, A. and Pizzoferrato, L. 2001. Nutritional value of mushrooms widely consumed in Italy. Food Chemistry 73(3): 321-325.

[6] Ares, G., Lareo, C. and Lema, P. 2007. Modified atmospheric packaging for the postharvest storage of mushrooms: a review. Fresh Produce 1: $32-40$.

[7] Biswas, A. K., Kumar, V., Bhosle, S., Sahoo, J. and Chatli, M. K. 2009. Dietary fibre as functional ingredients in meat products and their role in human health. International Journal of Livestock Production 2(4): 45-54.

[8] Codex Alimentarius. 2010. Report of the 31st session of the Codex Committee on nutrition and foods for specific dietary uses. ALINORM $10 / 33 / 26$.

[9] Devece, C., Rodríguez-Lopez, J. N., Fenoll, J.T., Catala, J. M., De los Reyes, E. and Garcia- Canovas, F. 1999. Enzyme inactivation analysis for industrial blanching applications: comparison of microwave, conventional, and combination heat treatments on mushroom polyphenoloxidase activity. Journal of Agriculture and Food Chemistry 47(11): 4506-4511.
[10] FAO. 1991. Protein Quality Evaluation. Rome: Food and Agricultural Organization of the United Nations.Foschia, M., Peressini, D., Sensidoni,

[11] A. and Brennan, C. S. 2013. The effects of dietary fibre addition on the quality of common cereal products. Journal of Cereal Science 58: 216-227.

[12] Hu, G., Huang, S., Cao, S. and Ma, Z. 2009. Effect of enrichment with hemicellulose from rice bran on chemical and functional properties of bread. Food Chemistry 115(3): 839-842.

[13] Hyung Hong-Ga, Soo Kim-Young and Seoup Song- Geun. 2005. Effect of oyster mushroom powder on bread quality. Journal of Food Science and Nutrition 10: 214-218.

[14] Khan, M.A. 2010. Nutritional composition and Hypocholesterolemic effect of mushroom: Pleurotus sajor-caju and Pleurotus florida: LAP Lambert Academic publishing Saarbrucken, G e r m a n y 111 .

[15] Ktenioudaki, A. and Gallagher, E. 2012. Recent advances in the development of high fibre baked products. Trends in Food Science and Technology 28: 4-14. 